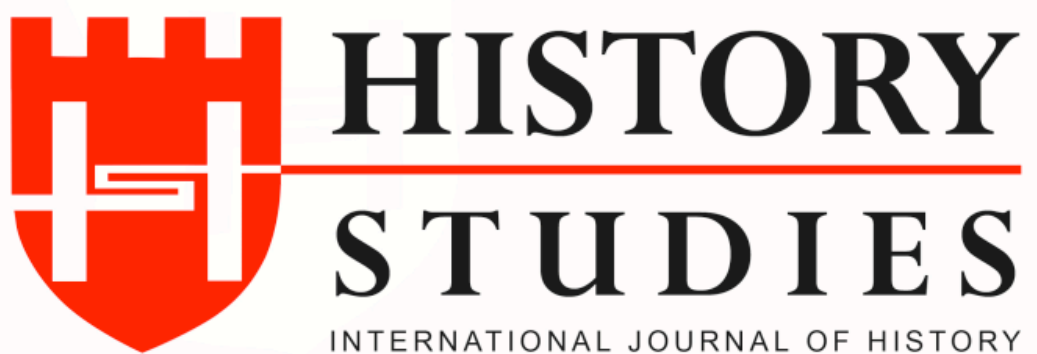

\author{
ISSN: 13094173 (Online) 1309 - 4688 (Print) \\ Volume 12 Issue 1, February 2020 \\ DOI Number: 10.9737/hist.2020.827 \\ Araştırma Makalesi
}

Makalenin Geliş Tarihi: 10.12.2019 Kabul Tarihi: 11.02.2020

Atıf Künyesi: Nil Orbeyi, “Mimar Sinan Yapılarında Çevre Duvarının Bir Bileşeni: Kapı”, History

Studies, 12/1, Şubat 2020, s. 211-225.

\title{
Mimar Sinan Yapılarında Çevre Duvarının Bir Bileşeni: Kapı
}

\author{
A Component of The Surrounding Wall in Mimar Sinan Structures: Door
}

\author{
Dr. Nil Orbeyi
}

ORCID No: 0000-0001-6577-1314

Mimar Sinan Güzel Sanatlar Üniversitesi

\begin{abstract}
Öz
Çalışmanın amacı, Mimar Sinan'ın İstanbul'da bulunan külliye çevre duvarlarının bileşenlerinden biri olan kapıların malzeme, boyut ve biçim özelliklerinin incelenmesi ve yapım teknolojisine ilişkin detayların belgelenmesidir. Çalışmanın çıkış noktası günümüzde harap durumda olması sebebiyle yap1 strüktürüne ait detayların görülebildiği Süleymaniye Külliyesi İmareti’nin bahçe giriş kapısı olmuştur. Çalışmada öncelikle bu kapı ile benzerlik gösteren, ana strüktürü basık kemer ile oluşturulmuş (strüktürel olarak sivri, teğet vb. farklı bir kemer ile desteklenmeyen), yakın zamanda onarılmamış ya da tercihen yapım sistemini meydana getiren detayların görülebildiği kapılar tespit edilmiștir. Sonraki aşamada güncel rölöveler, saha çalıșmaları ve arșiv belgeleri ile kapıların bileşenleri; malzeme, boyut ve biçim özelliklerine bağlı olarak incelenmiştir. Çalışmadan elde edilen veriler kapı bileşenleri olan; kemer, kapı ayağı, kapı kanatları ile tavan ve üst örtü başlıkları altında, karş1laştırmalı tablolar ve görseller eşliğinde sunulmuştur.
\end{abstract}

Anahtar kelimeler: Kapı, çevre duvarı, basık kemer, Mimar Sinan, külliye

\begin{abstract}
This study aims to examine the material, size and shape characteristics of the doors, which is one of the components of the Mimar Sinan complexes' surrounding walls in Istanbul and to document the details of their construction technology. The starting point of the study is the door of the garden, adjacent to the main structure of the Suleymaniye İmaret, where the construction system can be seen due to its ruined condition. In the study, firstly the doors, which are formed with a segmental arch (structurally not supported by a different arch like pointed arch or tangent arch, etc.), not recently repaired or preferably, in which details of the construction system can be seen, have been determined. In the next stage, the components of the doors were examined depending on their material, size, and shape properties accompanied by archival documents and the current surveys. The data obtained from the doors were presented comparatively under the arch, the door frame, the door leaves, and the ceiling with coping headings accompanied by comparative tables and visuals.
\end{abstract}

Key Words: Door, surrounding wall, segmental arch, Mimar Sinan, complex

\section{Giriş}

Etrafı kapatılmış bir mekana veya bir alana geçişi/girişi ve çıkışı sağlayan, gerektiğinde kanatları ile kapatılabilecek olan açıklığı tanımlayan kapıların boyut, biçim ve malzemesi, yapının inşa edildiği uygarlık ve dönem, banisinin kimliği/ekonomik durumu, kapının yapıdaki konumu, cephede arzulanan etki, kapının yüklendiği sembolik anlam ile çevre ve iklim 
koşulları gibi pek çok etmene bağlı olarak farklılaşmaktadır ${ }^{1}$. Özellikle anıtsal mimaride kapılar, tarihsel süreçte pek çok uygarlıkta olduğu gibi Osmanlı mimarlığında da fonksiyonel özelliğinin yanı sıra, özellikle giriș cephesinde simgesel bir öneme sahip olmuştur ${ }^{2}$. Pek çok yapı ögesinde olduğu gibi kapılarda da giriş cephesinde duyulan estetik kayg1, cepheden uzaklaştıkça azalmakta, bu da kapıların bileşenlerinin ve buna bağlı olarak kapıların biçimsel olarak farklılaşmasına sebep olmaktadır.

Kapılar, yapıların olduğu gibi, yapıyı çevreleyen duvarların da değişmez bileşenidir. Çeşitli işlevdeki yapılar ve yapı topluluklarının arazideki sınırlarını belirleyen, arsa, bahçe, avlu gibi açık mekanları çevresinden ayırmak amacıyla yapılmış, yapıyı sınırlayan duvarlar "çevre/ihata duvarı" olarak tanımlanmaktadır ${ }^{3}$. Çevre duvarları sivil mimaride güvenlik ve mahremiyet, anıtsal mimaride ise manevi sınırı tanımlamak amacıyla kullanılmıştır ${ }^{4}$. İşlevinin gerekliliğine ve yapının fonksiyonuna bağlı olarak çevre duvarının bileşenleri de farklılık göstermektedir. Örneğin pencereler sivil mimariye nazaran, yapının çevresi ile ilişkisini sağlayan ögeler olarak çoğunlukla anıtsal mimaride kullanılmıştır. Kapılar ise sivil mimaride güvenliği sağlayan ögeler olarak tanımlanırken, anıtsal mimaride "...çıkışların disiplinini sağlayan, yönlendirici..." ögeler olarak tanımlanmaktadır 5 . Çevre duvarları hangi amaçla yapılırsa yapılsın, yapıdan önce algılanan ilk kısım olma özelliği ile yapısal odak ve çevre ilişkisinde sınır koyucu, çevreyi şekillendirici bir özelliğe sahiptir. Çevre duvarının da odak noktası, girişleri temsil eden kapılardır.

Kapılar bu çalışmada Mimar Sinan'ın İstanbul'daki külliyelerinin çevre duvarlarında ele alınmış, benzer özellikteki örneklerin yapım sistemine yönelik detayların tespiti amaçlanmıştır. Yapım sisteminin ve yapı malzemesinin birleşim detaylarının görülebilmesi özellikle anıtsal mimaride çoğu zaman mümkün olamamaktadır. Çalışmanın çıkış noktası günümüzde tahrip olmuş durumda, yapım sistemine ait detayların görülebildiği Süleymaniye Külliyesi (Sultan Süleyman) İmareti ${ }^{6}$ 'nin güney-batı yönündeki bahçesinin etrafını çevreleyen duvarın giriş kapısı olmuştur. $\mathrm{Bu}$ doğrultuda çalışmada öncelikle imaretin kapısı ile benzer özellikler gösteren, ana strüktürü basık kemer ile oluşturulmuş (strüktürel olarak sivri, teğet vb. farklı bir kemer ile desteklenmeyen), kapı ayağ edilmiş (yekpare ve/veya farklı bir malzemeden yapılmamış), yakın zamanda restore edilmemiş veya yapım sistemini meydana getiren detayların görülebildiği kapılar tespit edilmiştir. Bu aşamada bu tanıma uyan kapıların yer aldığ 1 dört Mimar Sinan Külliyesi seçilmiş̧ir. Bunlar; Şehzade Mehmet Külliyesi, Süleymaniye Külliyesi, Kara Ahmet Paşa Külliyesi ve Kılıç Ali Paşa Külliyesi'dir. Külliyelerin çevre duvarlarında yer alan ve çalışma kapsamına alınan

\footnotetext{
${ }^{1}$ Celal Esad Arseven, "Kapı", Sanat Ansiklopedisi, C. 2, Milli Eğitim Basım Evi, İstanbul 1983, s. 941; Ayla Ödekan, "Cümle Kapısı", Türkiye Diyanet Vakfı İslam Ansiklopedisi, C. 8, İstanbul 1993, s. 115. Yaşar Çoruhlu, "Kapı”, Türkiye Diyanet Vakfi İslam Ansiklopedisi, C. 24, İstanbul 2001, s. 341.

${ }^{2}$ Giriş cephesinde ana giriş kapısının vurgulanışı zamanla taç kapı kavramını ortaya çıkarmıştır (Kuban, Doğan, 100 Soruda Türkiye Sanatı Tarihi, İstanbul 1981, s. 130).

${ }_{3}^{3}$ Metin Sözen-Uğur Tanyeli, Sanat Kavram ve Terimleri Sözlüğü, Remzi Kitabevi, İstanbul 1994, s. 111; Hüsrev Tayla, Geleneksel Türk Mimarisinde Yapı Sistem ve Elemanları, Taç Vakfı Yayınları, İstanbul 2007, s. 286; Nil Orbeyi, "Surrounding Wall of Mimar Sinan's Mosques: Components and Construction", Art-Sanat, S. 12, 2019, s.347.

${ }^{4}$ Somut anlamda bir yapı ögesi olarak tanımlanan kapı, tarihsel süreçte bu tanımın dışına çıkarak, soyut ve gerçek dünya arasındaki ilişkiyi düzenleyen simgesel bir öge olmuştur. Örneğin Japonya'da ve Çin'deki tapınak ve anıt mezar girişlerinde veya kutsal yollarda bulunan kapılar ile Roma Dönemi zafer takları bu bağlamda tanımlanabilen ögelerdir (Can Binan, “Kapı”, Eczacıbaşı Sanat Ansiklopedisi, Yem Yayınları, C. 2, İstanbul 1997, s. 944).

${ }^{5}$ Tayla, age, s. 286.

${ }^{6}$ Yapı hakkında detaylı bilgi için bkz. Ömer Lütfü Barkan, Süleymaniye Camii ve İmareti İnşaatı, C. 1 ve 2, Türk Tarih Kurumu Yayınları, Ankara 1972, 1979; Baha Tanman, "Sinan'ın Mimarisi İmaretler" Mimarbaşı Koca Sinan: Yaşadığı Çăg ve Eserleri, Ed. Sadi Bayram, Başbakanlık Vakıflar Genel Müdürlüğü, C. 1, İstanbul 1988, s. 340.
} 
kapılar Tablo 1'de, külliyelerin vaziyet planları üzerinde numaralandırılarak gösterilmiştir. Yapılan saha çalışmaları ile kapı bileşenlerinin malzeme, boyut, biçim özellikleri ve bileşenlerinin birbirleri ile ilişkisi incelenmiş, çalışmadan elde edilen veriler; kemer (basık kemer ve silmeli kaş kemer), kapı ayağı, tavan ve üst örtü ile kapı kanatları başlıkları altında sunulmuştur ${ }^{7}$. Sonuçta çalışma kapsamında ele alınan kapıların biçimlenme özelliklerinin, yapının banisinin ekonomik durumu, yapının fonksiyonu, kapının yapı içerisindeki konumu ve estetik kaygıya bağlı olarak farklılaşmasına rağmen, yapım tekniği, malzeme ve bileşenlerine bağl1 olarak benzerlik gösterdiği görülmüştür.

\section{Literatür araştırması}

Anıtsal mimaride kapılar geniş kapsamlı bir konu olması sebebiyle bugüne kadar farklı disiplinlerde pek çok araştırmacı tarafından ele alınmış, pek çok yayına konu olmuştur. Bu yayınlarda kapılar, ağırlıklı olarak mimari özelliklerine, bileşenlerine, biçimlerine ve süsleme özelliklerine bağlı olarak incelenmiş, dönemsel özellikleri çerçevesinde tanımlar, tipolojiler, kullanıldığı uygarlıklara bağlı karşılaştırmalar yapılmıştır. Kapıları geleneksel ve/veya anıtsal mimaride yapı elemanları başlı̆g 1 altında ele alan Uluengin ${ }^{8}$ ve Tayla'nın ${ }^{9}$ yayınlarında kapılar, kullanıldığ yere, çeşitlerine ve/veya bileşenlerine bağlı olarak örnekler üzerinde ele alınmıştır. Ayverdi $^{10}$, Çoruhlu ${ }^{11}$ ve Binan'ın ${ }^{12}$ yayınları ise kapıları tarihçe, kullanıldıkları yer ve biçimlerine bağlı tanımsal olarak ele alan çalışmalardır. Yayınlara, özellikle tezlere, azımsanmayacak oranda konu olan taç kapılar literatüre katkı sağlayan çalışmalarda; dönemsel olarak ele alınmış, cephe düzenindeki etkileri tartışılmış, biçimlenişleri ${ }^{13}$, süsleme öğeleri ile boyut ve oransal düzenleri detaylı olarak incelenmiştir ${ }^{14}$. Mimari ve sanat terimleri sözlükleri ile ansiklopediler kapı detaylarının tanımlanmasında çalışmaya katkı sağlayan diğer kaynaklardır ${ }^{15}$. Çalışma kapsamında kapı bileşenlerinin tanımlanmasında ve adlandırılmasında ağırlıklı olarak bu kaynaklardan faydalanılmıştır.

Issue 1

February

2020

${ }^{7}$ Literatürde, incelenen bileşenlerin terminolojisinde dil birliği bulunmamaktadır. Bu nedenle çalışmada öğelerin adlandırılmasında yaygın kullanımları tercih edilmiştir.

8 Fatin Uluengin-Bülent Uluengin-Bengü Uluengin, Osmanlı Anıt Mimarisinde Klasik Yapı Detayları, Yem Yayınları, İstanbul 2001.

${ }^{9}$ Tayla, age.

${ }^{10}$ Arseven, age.

${ }^{11}$ Yaşar Çoruhlu, "Kapı”, Türkiye Diyanet Vakfi İslam Ansiklopedisi, C. 24, İstanbul 2001, s. 341-342.

${ }^{12}$ Binan, age, s. 944-945.

13 Biçimlerinde mukarnaslı kavsaralarda yoğunlaşılmış, kapıların çoğunla dış mekana bakan yüzeyini meydana getiren bileşenler incelenmiştir.

${ }_{14} \mathrm{Bu}$ yayı̀lardan bazıları şunlardır; Ayla Ödekan, "Bir Mukarnaslı Portal Yarım Kubbesi Geometrik Şemadan Üçüncü Boyuta Geçiş Örneği”, İsmail Hakkı Uzunçarşılı’ya Armă̆an, Ankara 1976, 437-445; Orhan Cezmi Tuncer, "Birkaç Selçuklu Taçkapısında Geometrik Araştırmalar", Vakıflar Dergisi, Ankara 1982, S. 16, s. 61-76; Rahmi Hüseyin Ünal, "Osmanlı Öncesi Anadolu Türk Mimarisinde Taç Kapılar”, Ege Üniversitesi Edebiyat Fakültesi Yayınları, İzmir 1982; Ayla Ödekan, "Taçkapılar”, Mimarbaşı Koca Sinan: Yaşadı̆̆ı Çağ ve Eserleri, Ed. Sadi Bayram, Vakıflar Genel Müdürlüğü Yayınları, C. 1, İstanbul 1988, s. 521-529; Ayla Ödekan, "Cümle Kapısı", Türkiye Diyanet Vakfi İslam Ansiklopedisi, C.8, İstanbul 1993, s. 115-116; Orhan Cezmi Tuncer, "Kayseri Yedi Selçuklu Taçkapısında Geometrik Düzen", Vakıflar Dergisi, Ankara 1997, S. 16, s. 105-152; Orhan Cezmi Tuncer, “Anadolu Selçuklu Taçkapılarında Mukarnas”, I. Uluslararası Selçuklu Kültür ve Medeniyeti Kongresi Bildiriler, C. 2, Konya 2001, 361-387. Tezlerden bazıları ise şunlardır; Şakir Çakmak, Erken Osmanlı Döneminde Taç Kapılar (1300-1500), (Ege Üniversitesi Sosyal Bilimler Enstitüsü, Yayımlanmamış Doktora Tezi), İzmir 1999; Murat Karademir, Mimar Sinan Dönemi Yapılarında Taçkapılar, (Selçuk Üniversitesi Sosyal Bilimler Enstitüsü, Sanat Tarihi Anabilim Dalı, Yayımlanmamıș Doktora Tezi), Konya 2014.

${ }^{15}$ Adnan Turani, Sanat Terimleri Sözlüğ̈̈, Toplum Yayınları, Ankara 1975; Metin Sözen- Uğur Tanyeli, Sanat Kavram ve Terimleri Sözlüğ̈̈, Remzi Kitabevi, İstanbul 1994; Neslihan Sönmez, Osmanlı Dönemi Yapı ve Malzeme Terimleri Sözlüğ̈̈, Yem Yayınları, İstanbul 1998; Komisyon, Eczacıbaşı Sanat Ansiklopedisi, Yayına haz. Şakir Eczacıbaşı, Ali Gevgili Doğan Hasol, Bülent Özer, Yem Yayınları, 1997; Celal Esad Arseven, Sanat Ansiklopedisi, 
Orbeyi'nin $^{16}$ Mimar Sinan'ın İstanbul'daki külliye camilerinin çevre duvarlarının bileşenlerini malzeme, boyut ve biçim özelliklerine bağlı olarak rölöve, arşiv belgeleri ve saha çalışmalarına bağlı olarak incelendiği yayında araştırmanın yoğunluğu düşünülerek kapsam dışında bırakılan kapılar bu çalışmanın konusunu oluşturmaktadır. Çalışmada literatür taramasının yanı sıra kapıların güncel rölöveleri (tarafımızdan hazırlanan), saha çalışması ve Ali Saim Ülgen Arşivi'ne ait fotoğraflardan yararlanılmıştır.

\section{2. Çevre duvarlarındaki kapıların bileşenleri}

Çevre duvarının plan düzlemindeki biçimi, boyutları ve yapı/yapı toplulukları ile ilişkisi, çoğunlukla yapının konumlandığı parselin boyut ve biçimi ile ilişkilidir. Örneğin, geniş parsellerde konumlanan selatin camilerinde çevre duvarı, büyük olan dış avlu, iç avlu ve cami kapalı mekanını, bazen de bunlara ek olarak hazireyi çevreler. Daha küçük boyutlu, sıkışık kent dokusu içerisinde ve/veya komşu parsellere bitişik konumlanan bazı anıtsal yapılarda yapının etrafını tamamen çevrelemez ${ }^{17}$. Çevre duvarlarında, parselin biçimine ek olarak yapının ve yapı arazisinin parselde kaplandığı alan sınırlarına, etrafında yapıya ulaşım sağlayan sokak, cadde gibi bağlantı yollarının miktarına bağlı olarak birden fazla kapı bulunabilmektedir. Örneğin Süleymaniye Camii'nin çevre duvarlarında, caminin arazide kapladığ geniş alan sınırlarına paralel olarak 9 kapı, Şehzade Camii çevre duvarında ise 6 kapı bulunmaktadır. Kapıların boyut ve biçimleri çevre duvarındaki konumlarına göre farklılaşmaktadır ${ }^{18}$ (Tablo 1).

Milli Eğitim Basım Evi, İstanbul 1975; Komisyon, Türkiye Diyanet Vakfi İslam Ansiklopedisi, TDV Yayınları, Ankara 1940-1987; Celal Esad Arseven, İstilahat-ı Mi'mariyye (Osmanlı Dönemi Mimarlık Sözlüğü), Kaknüs Yayınları, İstanbul 2017.

${ }_{17}^{16}$ Orbeyi, age, s. 343-367.

17 Örneğin iki yönde komşu parsellere bitişik olan Çatalca Ferhat Paşa Küliyesi'nin sokağa bakan iki, üç yönde komşu parsellere bitişik olan Süleymaniye Külliyesi İmareti'nin ise sadece sokağa bakan bir cephesinde çevre duvarı bulunmaktadır (Çevre duvalarının planlanması ile ilgili detaylı bilgi için bkz. Orbeyi, age, s. 343-367). Yapı boyutlarına göre dar, dik açılı olmayan bir parselde konumlanan Yavuz (Sultan) Selim Medresesi'nde ise çevre duvarları bazı yönlerde yapı beden duvarlarına saplanmaktdır.

${ }^{18}$ Süleymaniye Camii çevre duvarındaki kapı çizimleri için bkz. Ali Saim Ülgen, Mimar Sinan Yapıları (Katalog), Ankara 1989, Plate 123.

\section{History Studies}




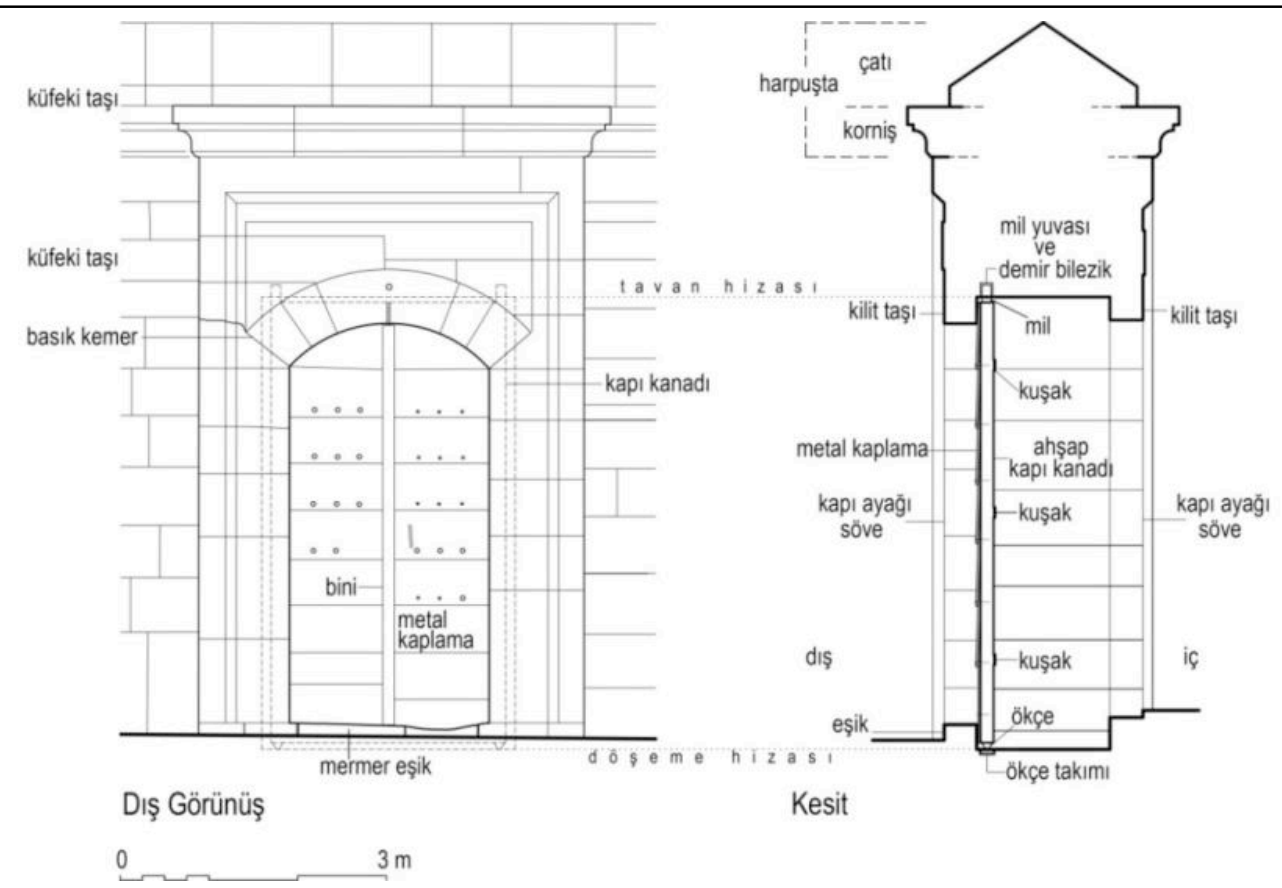

Şekil 1: Süleymaniye Camii kuzey çevre duvarı giriş kapısı rölövesi, 2017 (Tablo 1, Süleymaniye Külliyesi 2 no’lu kap1) (Nil Orbeyi)

Batur $^{19}$, mimarlıkta strüktürü “...bir yapının var olmasının (ayakta durmasının) vazgeçilmez

Volume 12

Issue 1

February

2020

koşulu olan elemanların dayanışık düzeni...." olarak tanımlamaktadır. 16. yüzyıl Osmanlı mimarlığında çevre duvarında bulunan bir kapı, boyut, biçim, malzeme ve süsleme öğelerine göre farklılaşmasına rağmen strüktürel ve işlevsel gerekliliklere bağlı olarak temel yapı ögeleri olan kemer, kapı ayağı, kapı kanatları, tavan ve üst örtünün birleşiminden meydana gelmiştir (Şekil 1). Bu bölümde kapıların bileşenleri bu başlıklar altında ele alınmıştır.

\subsection{Kemer}

Mimarlık tarihinde strüktür sistemlerinin gelişiminde önemli rol oynamış yapı elemanlarından biri olan kemer, Mezopotamya'da ortaya çıkmış ve yaygın olarak kerpiç malzemeyle uygulanmıştır. Antik Mısır'da taş malzeme kullanımı ile tarihsel süreçte farklı uygarlıklarda, farklı boyut ve biçimlerde uygulanmaya başlanmış, üslup belirleyici bir rol oynamıştır ${ }^{20}$. Osmanlı anıtsal mimarlığında kapı açıklıklarının geçilmesinde çoğunlukla basık kemer, teğet kemer, sivri kemer ve Bursa kemeri, tekil veya birden fazla kemerin bir arada kullanımı ile uygulanmışıı² ${ }^{21}$. Çalışma kapsamında incelenen kapılarda iki çeşit kemer kullanılmıştır: Basık kemer ve profilli kaş kemer ${ }^{22}$.

\footnotetext{
19 Afife Batur, Osmanlı Camilerinde Kemer / Strüktür-Biçim İlişkisi Üzerine Bir Deneme, (İstanbul Teknik Üniversitesi Doktora Tezi), İstanbul 1974, s. 30.

${ }^{20}$ Selçuk Mülayim, "Kemer”, Türkiye Diyanet Vakfi İslam Ansiklopedisi, C. 25, İstanbul 2002, s. 252.

${ }^{21}$ Arseven, age, s. 1014.

${ }^{22}$ Literatürde bu kemer biçiminin adlandırmasında kesin bir tanımlamaya rastlanılmamıştır. Tayla (2007: 306), İstanbul II. Beyazıt Camii hazire duvarı pencerelerinde kullanılan biçimlenmeyi “...kemerli bir kaş düzenlemesi...” olarak tanımlamaktadır. Buradan yola çıkarak incelediğimiz kapılarda kullanılan bu tanımlamaya benzer kemer cinsinin üst kısmı kaş kemere benzemekle birlikte içerdiği profiller (kepçe, kaval ve asaba) sebebiyle bu tanımla tam olarak örtüşmemektedir. İncelenen kemerlerin üst kısmının kaş kemer alt kısımlarının ise profillerden meydana gelmesi sebebiyle bu kemer cinsi çalışmada "profilli kaş kemer" olarak adlandırılmıştır.
}

\section{History Studies}


Tablo 1: Kapı ve bileşenlerinin yapı içerisindeki konumu ve boyutları (Cami planları, Necipoğlu ${ }^{23}$ üzerine Nil Orbeyi tarafından numaralandırılarak)

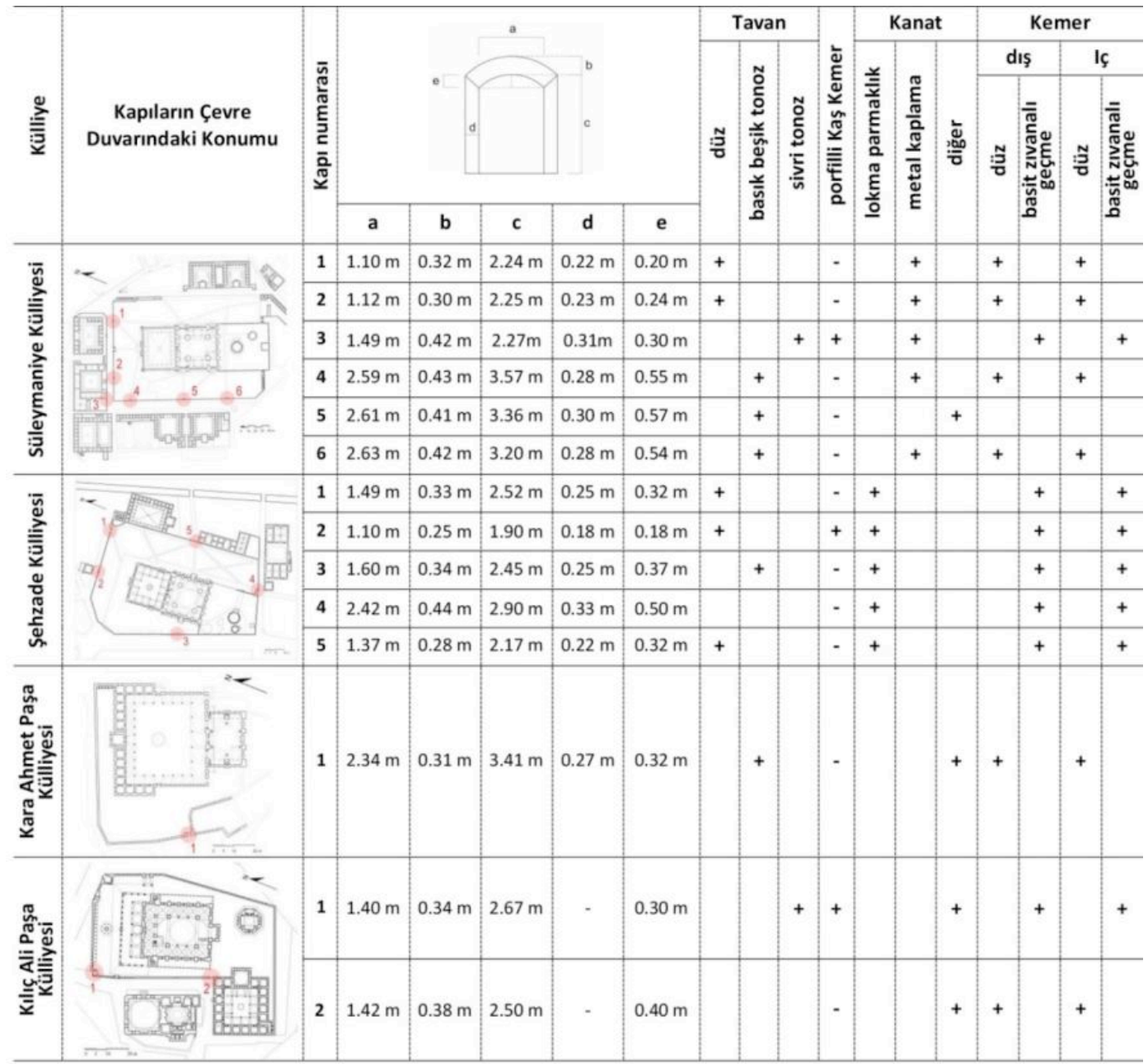

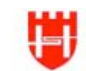

HISTORY STUDIES

216

Volume 12

Issue 1

February

2020

Basık kemer: Kemer yüksekliği kemer açıklığının yarısından az olan kemer, basık kemer olarak tanımlanmaktadır. Anıtsal mimaride çoğunlukla kapı açıklıklarının geçilmesinde, üzerinde fazla yük taşınmasının gerekli olmadığı yerlerde kullanılmıştır. İncelenen örneklerin çoğunda kapıların hem dış hem de iç mekana bakan yüzünde, bazılarında ise sadece dış mekana bakan yüzünde uygulanmıştır (Resim 1). Kemer taşları tek renk küfeki taşı olup düz veya basit zıvanalı geçme tekniğinde inşa edilmiştir. Kemer taşlarının ön ve arka yüzlerinde aynı geçme tekniği uygulanmıştır. ${ }^{24}$

Kemer açıklıkları ${ }^{25}$, ihtiyaç duyulan boyuta göre farklılaşmıştır. Ana girişlerin bulunduğu, yoğunluk yaşanan kapılarda (Örn. Resim 1j) geniş açıklıklar kullanılırken, daha az yoğunluk

\footnotetext{
${ }^{23}$ Gülru Necipoğlu, The Age of Sinan: Architectural Culture in the Ottoman Empire, Princeton University Press, Princeton-Oxford 2005.

${ }^{24}$ Osmanlı anıtsal mimarisinde özellikle daha karmaşık geçme motiflerrinin uygulandığı örneklerde, kemerin ön ve arka yüzü birden farklı biçimlenebilmektedir.

25 Kemer açıklı̆̆ı; bir kemerin oturduğu, iki duvar, iki ayak veya iki sütun arasındaki mesafe olarak tanımlanmaktadır (Arseven, age, s: 1018).
} 
olan kapıların (Örn. Resim 11) açıklığı daha azdır. Çalışmada incelenen kapı/kemer açıklıkları (Tablo1 a ölçüsü); $1.10 \mathrm{~m}-2.63 \mathrm{~m}$, kemer yükseklikleri; (Tablo 1, e ölçüsü) $0.18 \mathrm{~m}-0.57 \mathrm{~m}$ ve kemer taşı yükseklikleri (Tablo $1 \mathrm{~b}$ ölçüsü); 0.25 - $0.44 \mathrm{~m}$ arasında değişmektedir.
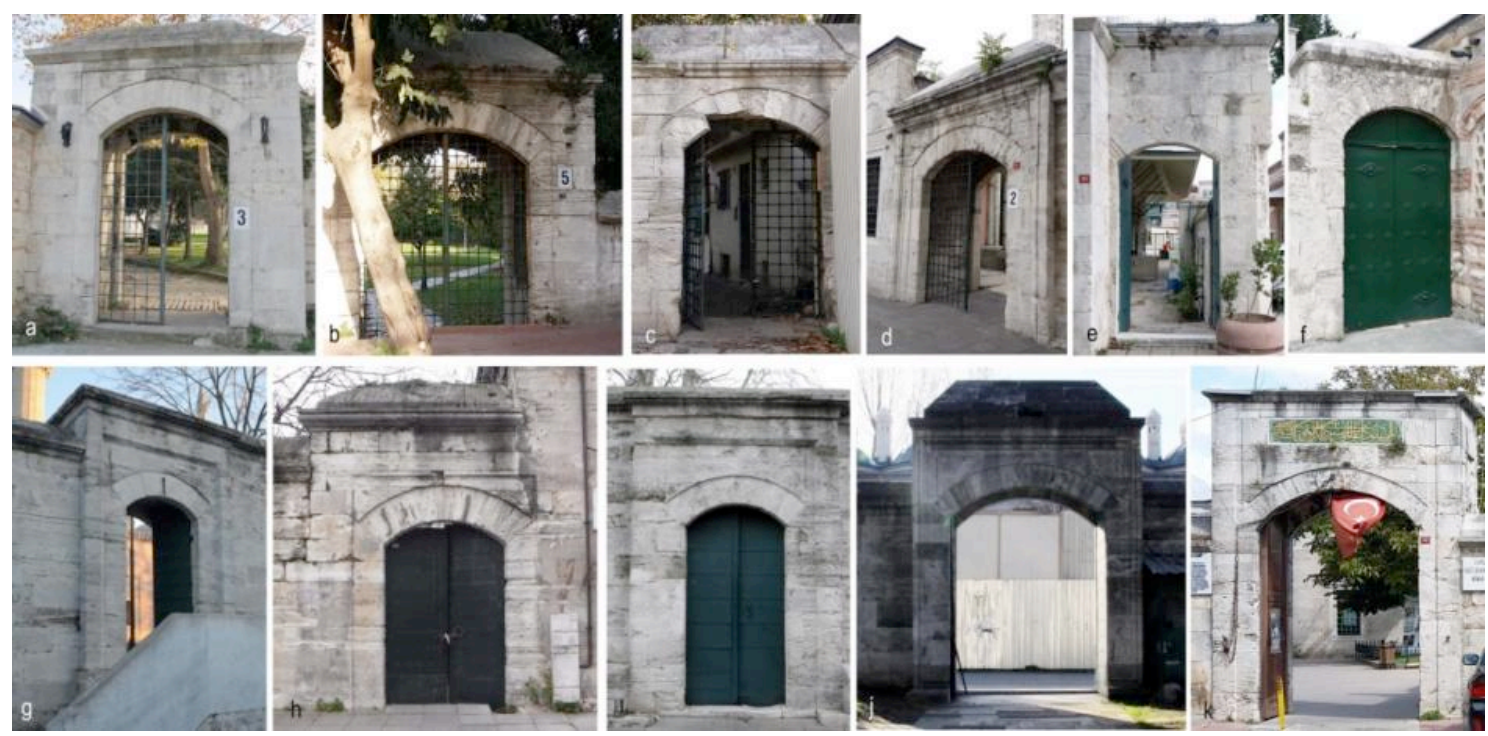

Resim 1. Basık kemerli kapı örnekleri; a-d) Şehzade Camii, 2019; e-f) Kılıç Ali Paşa Camii, 2019; g-j) Süleymaniye Külliyesi, 2017, k) Kara Ahmet Paşa Camii, 2019 (Nil Orbeyi)

Volume 12

Issue 1

February 2020

Profilli kaş kemer: Genellikle taç kapılarda basık kemerin iç mekana bakan yüzüne bitişik olarak görmeye alışkın olduğumuz profilli kaş kemer, çalışma kapsamındaki kapılarda da çoğunlukla benzer biçimde basık kemerin arka/iç mekana bakan yüzünde, kemere bitişik olarak uygulanmıştır. Şehzade Mehmet Camii'nde ise hem basık kemere bitişik hem de kapının iç avluya bakan yüzünde olacak biçimde bağımsız iki profilli kaş kemer kullanılmıştır Şehzade Mehmet Camii 2 nolu kapı, Resim 2a). Çevre duvarlarında, özellikle küçük boyutlu kapılarda daha nadir uygulanmıştır. Profilli kaş kemer, basık kemere bitişik olduğu durumlarda üst kısımda kanatların kapı strüktürüne bağlanması için yüzey oluşturmaktadır. Kapı kanatları kemerin üzengi kısmına açılan oyuklara bağlanır (Resim 2a,b,e,f). Kemerlerin malzemesi, küfeki ve mermerdir. Yaygın uygulamada üzengi kısmı mermer olup kemerin üst kısm1 küfekidir. Düşey millerin bağlandığı kısımda çoğunlukla mermer kullanımı aşınmalara karşı daha dirençli bir taş olması sebebiyle tercih edilmiş olmalıdır (Resim 2 a, d, e, f). Kemer biçimleri farklılaşmasına rağmen kepçe, asaba ve kaval profillerinin farklı biçimlerde birleşim ve tekrarından meydana gelmiştir (Resim 2).

Süleymaniye Külliyesi İmareti'nin bahçe kapısında, sadece üzengideki profilli kısım ile bu kısmın üzerindeki kemerin küçük bir bölümü günümüze ulaşmıştır (Resim 2d). Eski belgelerde kemerin biçimi hakkında herhangi bir bilgiye ulaşılamadığından kemerin biçimi bilinememektedir. Yakınında bulunan yapılar ile karşılaştırıldığında kemer, imaretin bitişiğinde yer alan Süleymaniye Külliyesi Tabhanesi'nin çevre duvarında yer alan giriş kapısına benzer biçimde profillerden meydana gelmiş bir kaş kemer ile tamamlanmış olabileceği gibi, imaretin ana giriş kapısındakine benzer olarak basık kemer ile de tamamlanmış olabilir (Resim 2e,f). Ancak günümüzde mevcut olan profilli kısım ile tuğla örgü tonoz arasındaki mesafe dikkate alındığında silmeli kaş kemer için gerekli mesafe bulunmadığı, bu nedenle de basık kemer veya benzeri bir kemer ile tamamlanmış olabileceği düşünülebilir. 


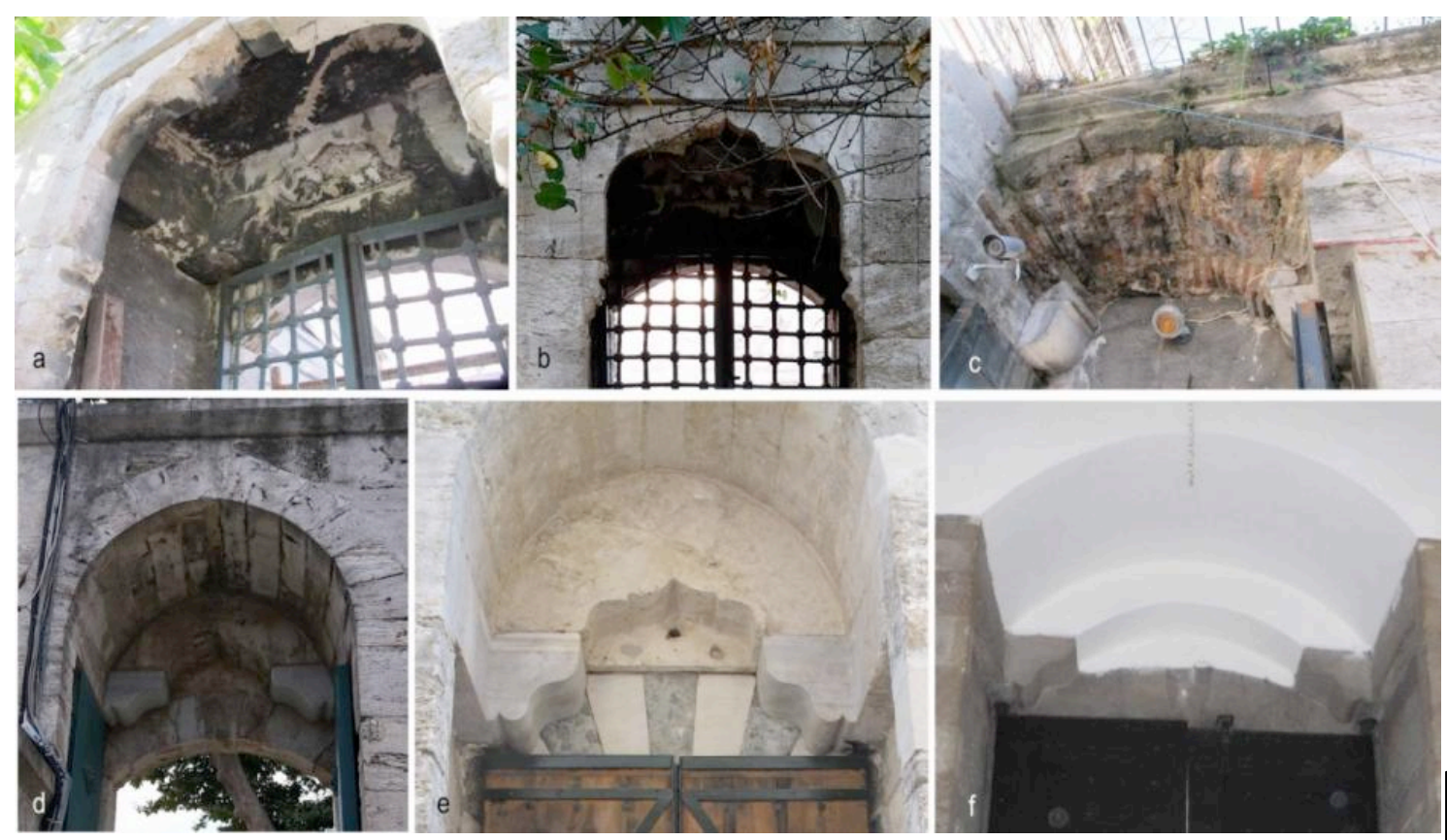

Resim 2: Profilli kaş kemer örnekleri; a-b) Şehzade Camii kuzey çevre duvarı, 2019; c) Süleymaniye Külliyesi İmareti bahçe girişi, 2017; d) Kılıç Ali Paşa Camii kuzey çevre duvarı, 2019; e) Süleymaniye Külliyesi Tabhanesi çevre duvarı, 2017; f) Süleymaniye Külliyesi İmareti çevre duvarı ana girişi, 2017 (Nil Orbeyi)

\subsection{Kapı ayağı/Söve}

Literatürde açıt ayağı, kapı ayağı, yan ayak, kemer ayağı, giriş açıklığı sövesi, söve vb. ifadeler ile adlandırılan bileşen, kemerin oturduğu, kapı strüktürünün ayakta durmasını destekleyen kısım olarak tanımlanmaktadır ${ }^{26}$. Kapı ayakları, bileşeni oldukları duvardan bağımsız, yekpare malzemeden yapılmış olabileceği gibi duvarın devamı niteliğinde de inșa edilmişlerdir. İncelenen örneklerin tamamında kapı ayakları strüktürden bağımsız bir bileşen olarak değil, çevre duvarı ile bitişik, duvar örgüsünün devamı olacak biçimde yapılmıştır. Kapıların bulunduğu çevre duvarları kesme küfeki taşından yığma olarak inşa edilmiş olup derzli veya derzsiz olmak üzere iki farklı düzende uygulanmıştır. Taş yükseklikleri maksimum $40 \mathrm{~cm}$, uzunlukları ise maksimum $120 \mathrm{~cm}$ 'dir. Derzli örneklerde bağlayıcı olarak kireç veya horasan harcı kullanılmıştır. Taşların boyutları yapıdan yapıya, hatta aynı yapı içerisinde de farklılık gösterebilmektedir. Bu nedenle taş boyutlarında standart bir ölçüden söz edilemez. ${ }^{27}$

Kap1 ayağının örgü tekniği ve malzemesi çoğunlukla bulunduğu çevre duvarı ile benzer özellikler göstermektedir ${ }^{28}$ (Resim 1). Şehzade Camii kuzey çevre duvarında olduğu gibi duvardan taşkınca yapılmış bazı örneklerde kemer ayağı ile çevre duvarının örgüsü farklı teknikte yapılmıştır. Şehzade Camii kuzey çevre duvarı harçlı kesme taş örgü tekniğinde inşa edilmiş iken kapı ayakları, daha özenli bir işçilikle yapılmış harçsız kesme taş örgüdür (Resim $3 a, b)$.

\footnotetext{
${ }^{26}$ Turani, age, s. 64; Arseven, age, s.941, Binan, age, 944.

27 Orbeyi, age, s. 354.

${ }^{28}$ İstanbul'daki Sinan yapılarının çevre duvarlarının ana caddeye ve ya avluda yer alan türbe gibi yapılara bakan bölümlerinin malzeme, işçilik ve teknik açıdan daha özenli, estetik yönü daha çok vurgulanarak biçimlenmiş kesme taş örgü tekniğinde yapıldığı, gözden daha uzak çoğunlukla ara sokaklarda yer alan bölümlerinin ise taş/tuğla almaşık ya da düzgün yatay derzli kaba yonu örgü sisteminde yapıldığı görülmektedir (Orbeyi, age, s. 353).
} 

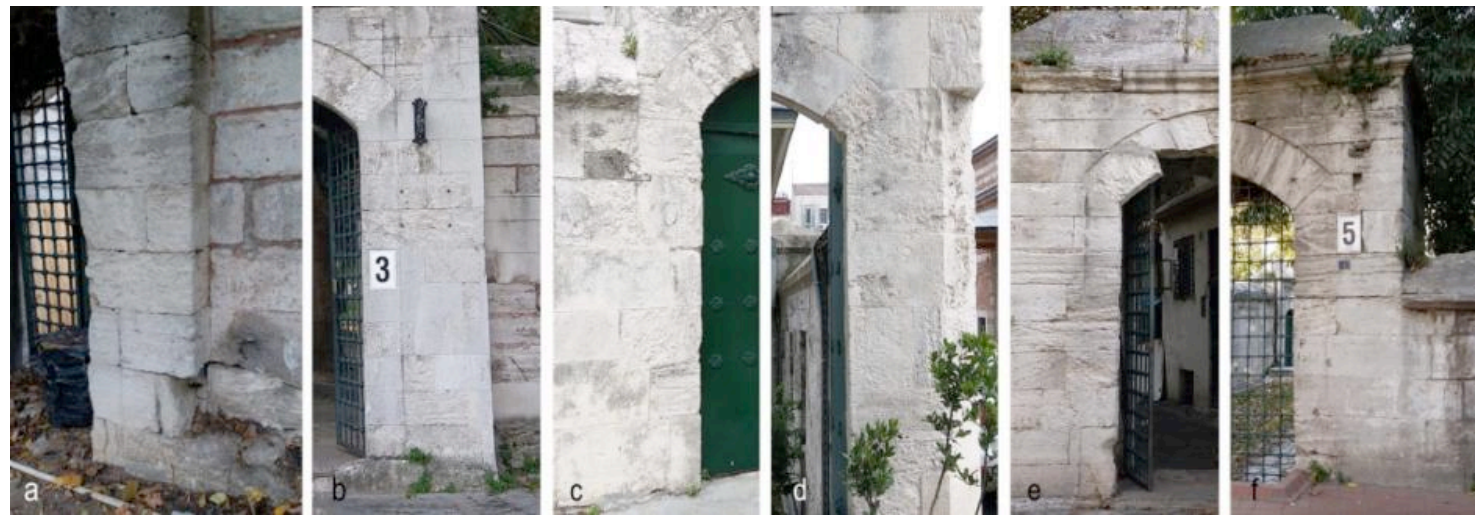

Resim 3: Kapı ayağı; a, b) Şehzade Camii kuzey çevre duvarı, 2019; c, d) Kılıç Ali Paşa Camii kuzey çevre duvarı, 2019 ; e, f) Şehzade Camii doğu çevre duvarı, 2019 (Nil Orbeyi)

Kapının genelinde olduğu gibi kapı ayaklarında da süsleme ögesi kullanılmamıştır. Kapı ayağı ve çevre duvarın ayrımı, ayak genişliğinin duvar yüzeyinden çökertilmesi ile vurgulanmıştır. Kapı ayaklarının genişliği kemer kalınlığı ile orantılı olup $0.18 \mathrm{~m}-0.33 \mathrm{~m}$ arasında değişmektedir (Tablo 1).

Zeminde kapı ayaklarının arasında yekpare taştan birer eşik bulunur. Eşik kapının ayırdığı iki mekanın döşeme hizalarından daha üst seviyesinde planlanan, çoğunlukla yekpare mermerden yapılmış bir öğe olarak kapı kanatlarının altında oluşan boşluğun kapatılmasını sağlamanın yanı sıra ayakların alt kısımlarının birbirine yaklaşmasını önleyerek kap1 strüktürünün stabilitesini sağlamaktadır ${ }^{29}$. Mimaride kapıların değişmez bileşenlerinden biri olan eşikler anıtsal mimaride aşınmadan dolayı yıpranma payını asgariye indirmek amacıyla taş (çoğunlukla mermer) malzeme ile yapılmıştır. İstanbul'da bulunan pek çok tarihi yapı yapıda olduğu gibi, çoğunlukla alt yapı nedeniyle zemin kotunun yükseltilmesi bazı yapıların girişlerinin (Resim 4 b,c,d) ve eşiklerinin yol kotunun altında kalmasına sebep olmuştur. Örn. Şehzade Camii Dede Efendi Sokağı'na cepheli çevre duvarında bulunan kapılar ile Süleymaniye İmaret kapılarının eşikleri zeminin altında kalmış bu durum kapıların görsel bütünlüğünü de olumsuz yönde etkilemiştir (Resim 1h, 3f).

\subsection{Tavan ve üst örtü}

İncelenen örneklerde kapı boşluğu düz tavan veya tonoz ile geçilmiş, üzeri ise harpuşta ile örtülmüştür.

Tavan biçimlenmesi: İncelenen örneklerde kapı boşlukları düz tavan veya basık ya da sivri kemerli beşik tonoz ile geçilmiştir. Düz tavan, Süleymaniye Camii kuzey çevre duvarı (Tablo 1, Resim 4a) örneğine benzer olarak tamamen düz bırakılmış iken çoğu uygulamada tavan strüktürünü destekleyen, tavanın kısa kenarı boyunca devam eden silmeler kullanılmıştır (Resim 4b, c, d). Bu örneklerde kapı kanatları silmelere bağlanmıştır. Silmeler ve konsollar, küfeki taşından veya mermerden yapılmıştır. Sıvalı olmayan Şehzade Mehmet Camii örneklerinde düz plaklar kullanıldığı görülmektedir (Resim 4c, d). Taş plakların yüzeyinde Resim 4c örneğinde oyma tekniğinde yapılmış bezeme öğeleri uygulanmıştır. Resim 4d örneğinde ise taş plaklar silmelerin yanı sıra kapı açıklığının dört yönünde bulunan konsollara oturtulmuştur (Resim 4d). Kolay ve Çelik'in (2007) çalışmalarında sundukları görsellerde

\footnotetext{
${ }^{29}$ Arseven, 2017, age, s. 29; Arseven, age, s. 941.
}

\section{History Studies}


Süleymaniye Camii güney-doğu çevre duvarı kapısında uygulanan düz tavanda büyük boyutlu taş plakların duvarlara oturtulan demir kirişler tarafından taşıtıldığı görülmektedir ${ }^{30}$.

Süleymaniye İmaret'inin bahçe kapısı (Tablo1, Süleymaniye Külliyesi 3 no'lu kapı) ile Kara Ahmet Paşa Camii çevre duvarının batı giriş kapısı (Tablo 1, Kara Ahmet Paşa Külliyesi 1 no'lu kapı) açıklığı basık beşik tonoz, Kılıç Ali Paşa Camii kuzeybatı giriş kapısı (Tablo 1, Kılıç Ali Paşa Külliyesi 1 no'lu kapı) ise sivri beşik tonoz ile geçilmiştir. Basık beşik tonozlar kapının iç ve dış mekana bakan yüzlerinde uygulanmış olan basık kemerlerin arasında, basık kemerin eğimi ile benzer eğimde inşa edilmiş olup tuğla örgüdür (Resim 2c). Süleymaniye Külliyesi İmareti'nin kapısında tuğla örgünün üzerinde taş örgünün (küfeki) devam ettiği görülebilmektedir. Kapının üst kısmı yine küfeki taşı ile silmeli bir geçiş ile tamamlanmaktadır (Resim 2c). İç kısımda bulunan tuğla örgünün üzeri küfeki taşı ile kaplanmış olmalıdır. Kılıç Ali Paşa Camii örneğinde beşik tonoz örgüsü ise küfeki taşı ile yapılmıştır. Süleymaniye Külliyesi İmareti örneği benzer kapıların da aynı biçimde inşa edilmiş olabileceğini düşündürmektedir.
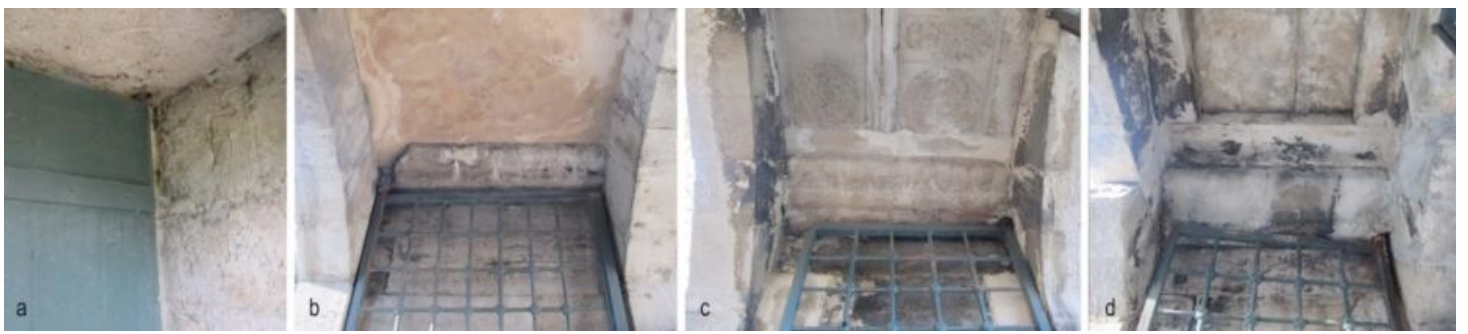

Resim 4: Kapı boşluğu düz tavan biçimlenmesi; a-b) Süleymaniye Camii, 2019; c-d) Şehzade Camii, 2019 (Nil Orbeyi)
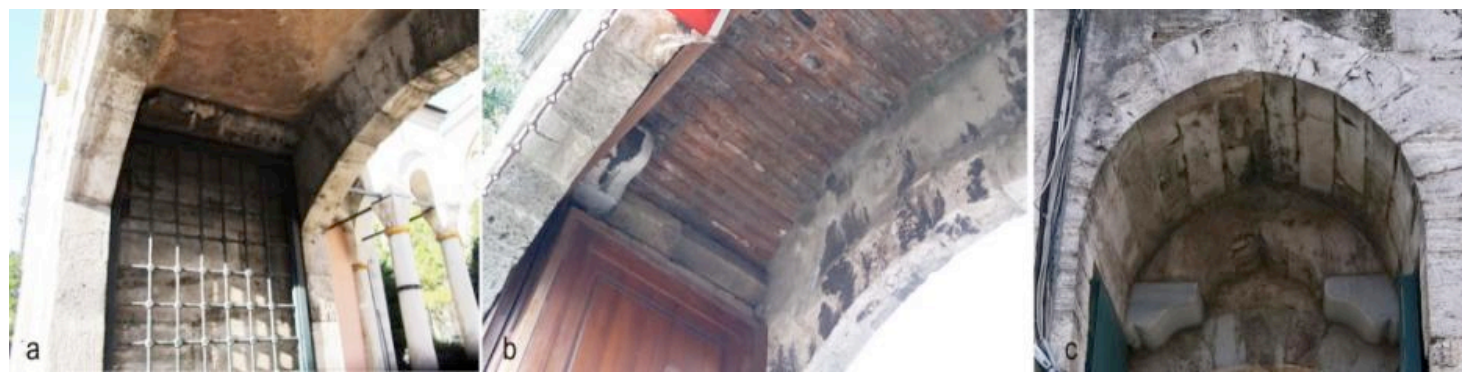

Resim 5: Kapı boşluğu tonoz biçimlenmesi, 2019; a) Şehzade Camii batı girişi, 2019; b) Kara Ahmet Paşa Camii batı girişi, 2019; c) Kılıç Ali Paşa Camii kuzeybatı girişi, 2019 (Nil Orbeyi)

Üst örtü/Harpuşta: Duvar semeri de denilen harpuşta, sözlük manasıyla yanlardan ve üst kısımdan iklimsel etkilere açık bir duvarı korumak amacıyla, duvarın üst kısmına eklenen koruyucu öğe olarak tanımlanmaktadır ${ }^{31}$. Geleneksel Osmanlı mimarlığında harpuştalar; sıva, çamur harç, saz, çaplama, alaturka kiremit, klasik tuğla, moloz taş, yassı (plak) taş ve kesme taş malzeme ile yapılmış iken anıtsal mimaride çoğunlukla taştan yapılmıştır². Çalışma

\footnotetext{
${ }^{30}$ Konu hakkında detaylı bilgi ve görseller ile ilgili bkz. İlknur Kolay - Serpil Çelik, "Malzeme ve Teknoloji" Bir Şaheser Süleymaniye Külliyesi, Ed. Selçuk Mülayim, T.C. Kültür ve Turizm Bakanlığı Yayınları, Ankara 2007, s. 140.

${ }^{31}$ Celal Esad Arseven, "Duvar Semeri”, Sanat Ansiklopedisi, C. I, Milli Eğitim Basım Evi, İstanbul 1983, s. 496; Arseven, age, 2017, s. 73.

${ }^{32}$ Tayla, age, s. 286.
} 
kapsamında incelenen örneklerde harpuştalar kesme küfeki taşından harçlı ve harçsız olarak yapılmış olup iki bölümden oluşmaktadır. Birincisi suyun akmasına olanak sağlayan eğimli üst kısım, ikincisi ise duvar ile birleşim yerinde bulunan, suyun duvardan uzaklaştırılmasını sağlayan korniş kısmı. Bu iki kısmın malzemeleri benzer olup çoğunlukla ayrı taş bloklarının üst üste oturtulması ile oluşturulmuştur. ${ }^{33}$ Harpuştaların malzemesi benzer olmasına rağmen bileşenlerinin boyut ve biçimleri standart olmayıp yapıdan yapıya ve hatta aynı yapı içerisinde farkl111k göstermektedir. ${ }^{34}$

Kapıların bulunduğu çevre duvarlarının yüksekliği, incelenen örneklerin çoğunluğunda kapı yüksekliğinin altındadır. Bu örneklerde çevre duvarının harpuştası kapının başladığı noktada sonlandırılmış, kapının üzerini örten harpuşta duvar harpuştasından bağımsız biçimlendirilerek kap1 vurgulanmıştır (Resim 1). Duvar yüksekliği ile kapı yüksekliğinin eşit olduğu örneklerde kapıların üzerini örten harpuşta çevre duvarının harpuştası devam ettirilerek oluşturulmuştur (Resim 1). Örneğin, Süleymaniye Camii kuzey çevre duvarı kapısında, çevre duvarının harpuştasının çatı kısmı kesintisiz devam etmekte, korniş kısmı kapının olduğu bölümde plan şeması ile benzer olarak dış mekana doğru çıkıntı yapmaktadır (Şekil1, Resim 11). Her iki durumda da kapının vurgulanması sağlanmıştır.

\subsection{Kapı kanatları}

Geleneksel mimaride kasa ve kasaya bağlanan kanat, kapının açılıp kapanabilir olma

HISTORY

STUDIES

221

Volume 12

Issue 1

February

2020

özelliğini sağlayan iki bileşendir. Anıtsal mimaride ise kanatlar kasaya değil, tavana veya tavanda bulunan silmelere ve zemine bağlanmaktadır. Bu nedenle kasaya ihtiyaç duyulmaz. Çevre duvarlarında kapılar çoğunlukla çift kanatlı olup aralarında birer bini bulunur. Çalışma kapsamında incelenen kapıların tamamı da çift kanatlı olup metal kaplama ve lokma parmaklı olmak üzere iki farklı biçimde uygulanmıştır.

Metal kaplama kapı kanatları: Metal kaplama kanatlar, mıllama/çakma tekniğinde yapılmış ahşap (çoğunlukla meşe kullanılmış) kanatların birbiri üzerine bindirilmiş metal levhalar (levha dövme demir) ile kaplanması ile oluşturulmuştur ${ }^{35}$. Arseven ${ }^{36}$, mıllama kapıyı, ahşap parçaların lambalı veya lambasız olarak birbiri üzerine bindirilip kuşaklarla sabitlenmesi ile oluşturulan kapı olarak tanımlamaktadır. Bu teknik geleneksel mimaride çoğunlukla han kapıları, ahır kapıları ve avlu kapılarında, anıtsal mimaride ise çevre duvarlarının kapılarında kullanılmıştır. Metal kaplama kapı kanatları incelenen kapılarda iki farklı biçimde uygulanmıştır. Birinci teknikte ahşap parçalar yan yana getirilerek arka yüzlerinden üst, orta ve alt taraflarından ahşap kuşaklarla sabitlenmesi ile yapılmıştır. İkinci teknikte ise ahşap parçalar kapı kanadının dört yüzünde bulunan pervazlar arasına sabitlenir ${ }^{37}$. Süleymaniye Külliyesi’nin çevre duvarlarındaki Tablo 1'deki 1-4 ve 6 numara ile gösterilmiş kapılarda uygulanmıştır. İncelenen örneklerde kapı kanatları ahşap parçaların lambalı veya lambasız olarak yan yana getirilmesi ve arkalarından, kalın kesitli ve yatay, genellikle üç adet kayıt (puştivan, püştivan) ile sabitlenmesi ile oluşturulmuştur ${ }^{38}$. Yatay kuşaklar ahşap kırlangıç geçme ile bağlanmıştır.

\footnotetext{
33 Ancak Kılıç Ali Paşa Camii çevre duvarında olduğu gibi, yekpare taş bloğundan yapıldığı nadir örnekler de mevcuttur (Orbeyi, age, s. 357).

${ }^{34}$ Yapıların çevre duvarı harpuşta biçim ve boyutları hakkında detaylı bilgi için bkz. Tayla, age, 286-323, Orbeyi, age, s. 356-359.

${ }^{35}$ Bülent Uluengin, Mimari Metaller Özellikleri, Bozulma Nedenleri, Koruma ve Restorasyon Teknikleri, Birsen Yayınevi, İstanbul 2006, s. 81; Tayla, age, s. 131.

${ }_{37}^{36}$ Arseven, age, s. 944, 949.

${ }^{37}$ Arseven, age, 944.

${ }^{38}$ Sönmez, Osmanlı Dönemi Yapı ve Malzeme Terimleri Sözlüğü, Yem Yayınları, İstanbul 1998, s. 87; Arseven, 2017, age, s. 55.
} 
Süleymaniye Külliyesi İmareti kapısında ise kuşak bulunmaz. Ahşap parçalar, kanadın üst ve alt kısımlarında bulunan ahşap pervazlara sabitlenmiştir (Resim 7b).

Ahşabın dış hava koşullarından etkilenmemesi/korunması amacıyla kanatların sokağa cepheli dış yüzeyi, yapılara göre değişmekle birlikte yaklaşık $30-40 \mathrm{~cm}$ yüksekliğinde metal levhalar ile kaplanmıștır. Kaplama, metal levhaların yalı baskısına benzer biçimde birbirinin üzerine bindirilmesi ve para başlı çivilerle ahşap yüzeyine sabitlenmesi ile oluşturulmuştur. Metal levhaların genişlikleri ise genellikle kanadın genişliği ile benzerdir. Bazı örneklerde kanadın yan yüzleri ile arka kısmı da ayrı metal levhalar ile kaplanmıştır (Resim 7b,c). Bazı örneklerde ise kanadın zemindeki kısmının aşınmasının en aza indirgenmesi amacıyla bu kısma metal bir levha eklenmiştir (Resim 7a).

Kanatların kapı strüktürüne bağlantısında düşey miller kullanılmıştır. Miller üst kısımda ahşabın (seren) uç kısımlarının silindir şeklinde uzatılması ile oluşturulmuştur. Alt kısma ise kanadın altına ökçe adı verilen koni biçimli bir mil yerleştirilmektedir ${ }^{39}$. Döşeme taşında millerin gireceği oyuklar açılmaktadır. Aşınmayı minimuma indirmek amacıyla, miller metal bilezik $^{40}$ ile delikler ise kurşun ile kaplanmaktadır ${ }^{41}$. Döşeme taşına açılan oyuğun içerisine, ortasında bir oyuk bulunan kare veya dikdörtgen, kapı ökçesi veya ahen-i ökçe olarak adlandırılan demir bir öge yerleştirilmektedir. $\mathrm{Bu}$ öge, döşeme taşına açılan kare ya da dikdörtgen bir oyuk içine yerleştirilip etrafina kurşun dökülmesi ile sabitlenmektedir ${ }^{42}$. Genellikle üst yüzü dört yöne eğimlidir. Ancak incelenen örneklerde ökçe ve içinde bulunduğu oyuk tahrip olmuş olduğundan benzer biçimlenme görülememiştir (Resim 6).

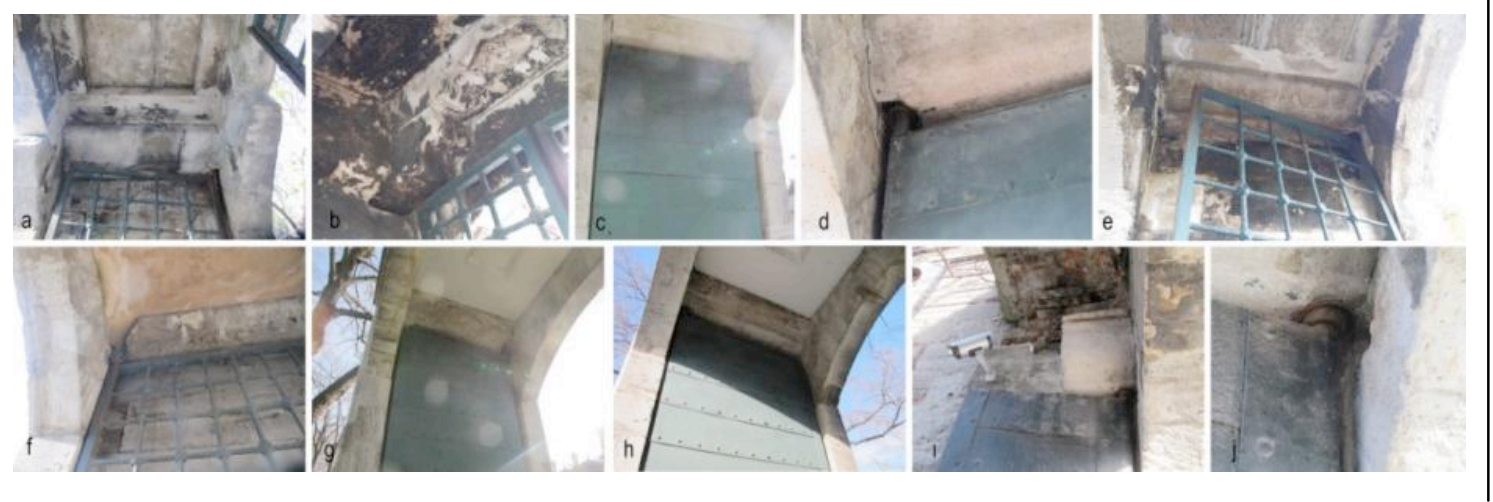

Resim 6: Kapı mili, üst kayıt; a, b, f, e) Şehzade Camii, 2019; c, d, g, h, j) Süleymaniye Camii, 2017; 1) Süleymaniye Külliyesi İmareti, 2017 (Nil Orbeyi)

Lokma parmaklıklı kapı kanatları: Anıtsal mimaride pencerelerde uygulanan teknik ile benzer olarak kanatların tamamı lokma parmaklıktan oluşmuștur. Lokma parmaklıklar açıklığı kapatmak için gerekli kanadın boyutlarında demir malzemeden dikdörtgen bir çerçeveye sabitlenmiştir. Yaklaşık eşit uzunlukta düşey ve yatay parmaklıkların kesişim noktalarında lokma denilen bileşen ile birbirine sabitlenmesi ile oluşturulmuştur. Kap1 strüktürü ile bağlantısı, metal kaplama kapı ile benzer olarak düşey miller ile sağlanmıştır (Resim 2a).

\footnotetext{
${ }^{39}$ Sönmez, age, s. 85.

${ }^{40}$ Ahşap pencere ve kapıların sabitlenmesinde tavana açılan oyuğun içerisine milin aşınmasının önlenmesi için yerleştirilen silindir demir öğe (Sönmez, age, s. 30).

${ }^{41}$ Benzer kapılar Hattiler, Asurlar, Antik Mısır ve Roma İmparatorluğu'nda da kullanılmıştır (Arseven, age, s. 950).

${ }^{42}$ Sönmez, age, s. 24.
} 


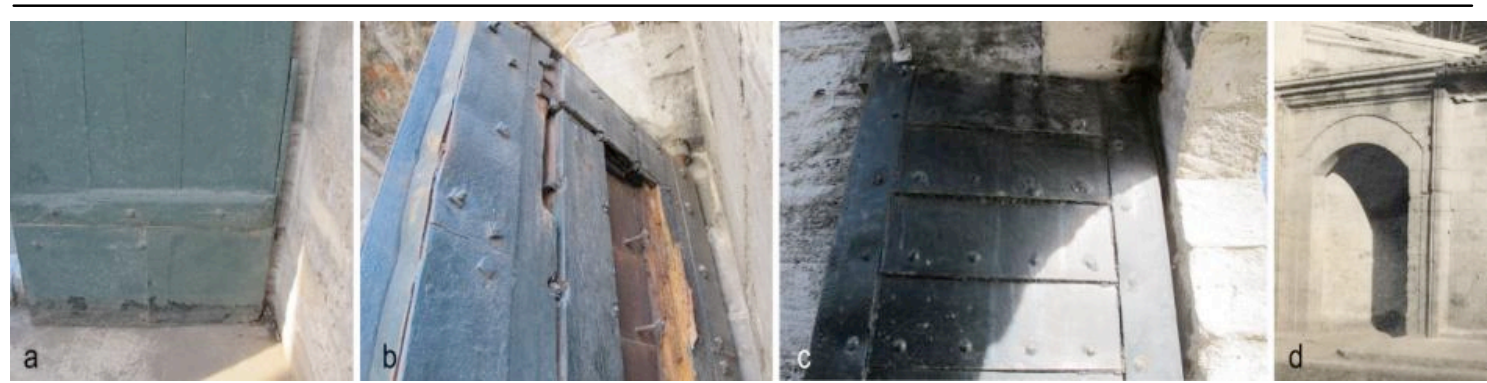

Resim 7: Kapı kanatları; a) Süleymaniye Camii, 2017 (Nil Orbeyi); b, c) Süleymaniye Külliyesi İmareti, 2017 (Nil Orbeyi); d) Şehzade Camii, 1957-1961 (URL1)

Şehzade Camii'nin çevre duvarlarındaki kapı kanatlarının tamamı lokma parmaklıdır. Ancak 20. yüzyılın ikinci yarısına ait Ali Saim Ülgen Arşivi’nde yer alan fotoğraflarındaki kapıda kanat bulunmamaktadır (Resim 7d). Özgün durumunda kanat olup olmadığı, şayet varsa malzemesi hakkında bilgi edinilememiştir (Tablo1, Şehzade Külliyesi 3 numaralı kapı).

\section{Değerlendirme ve sonuç}

$\mathrm{Bu}$ çalışmadan elde edilen verilerle aşağıdaki sonuçlara ulaşılmıştır:

HISTORY STUDIES

223

Volume 12

Issue 1

February

2020

- Çalışma kapsamında incelenen kapıların ana yapı malzemesi küfekidir. Kemerler, kapı ayakları, tavan kaplaması, tavandaki silmeler ve üst örtü (harpuşta) küfeki taşından yapılmıştır. Mermer kullanımı kapı geneline bakıldığında küfeki taşına göre daha düşük orandadır. Bazı kapıların tavan geçişlerindeki silmeler ve eşikleri ile düz tavanlarda tavan plaklarında mermer kullanılmıştır. Tuğla, eğrisel tavanda (tonozlarda) kullanılmıştır. Süleymaniye Külliyesi İmareti kapısının üst kısmı büyük ihtimalle küfeki kaplı olmasına rağmen tonoz tuğla ile örülmüştür. Metal malzeme millerde, lokma parmaklıklarda ve kanatların kaplanmasında kullanılmıştır.

- Basık kemer incelenen her kapıda bulunmasına rağmen profilli kaş kemer sadece Şehzade Mehmet Camii, Kılıç Ali Paşa Camii ve Süleymaniye Külliyesi İmareti örneklerinde görülmektedir. Profilli kaş kemerin özellikle iç kısımda basık kemer ile tavan arasındaki mesafenin düz tavanlı örneklere göre daha fazla olduğu kapılarda uygulandığ görülmektedir. Diğer örneklerde kapı boşluğunun iç ve dış kısmında birbirine eş iki basık kemer kullanılmıştır. Bu durumda basık kemerlerin arası düz ve ya basık beşik tonoz ile geçilmiştir (Resim 5a, b). Profilli kaş kemerin kullanıldığı örneklerde ise, nadir uygulamalardan biri olan Şehzade Mehmet Camii örneği hariç, kapının iç mekana bakan kısmında tonozun haricinde başka eleman kullanılmamıştır (Resim 5 c).

- Kılıç Ali Paşa Camii örnekleri haricindeki kapılarda çevre duvarı ile kapı ayağının ve kemerin ayrımı ayak genişliği ve kemerin üst hizasının duvar yüzeyinden çökertilmesi ile belirginleştirilmiştir (Resim 3). Kılıç Ali Paşa Camii örneklerinde kapı ayağı veya kemer örgüsü ile duvar örgüsü ayrımı herhangi bir şekilde belirtilmemiştir (Resim 1 e, f). Kapı strüktürü duvar örgüsünün içerisinde çözümlenmiştir.

- Kapıların boyutlarında bir standart yoktur. Aynı yapıdaki kapı boyutlarında da farklılıklar görülmektedir. Kapı açıklığının kap1 yüksekliğine oranı; 3 kapıda $\sim 1,2,4$ kapıda $\sim 1,5,3$ kapıda $\sim 1,7$ ve 4 kapıda $\sim 2$ 'dir (Tablo 1). Bu boyutlara bağlı olarak oransal bir benzerlikten de söz edilemez.

Çevre duvarları, camilerin boyutlarına ve malzeme özelliklerine bağlı olarak biçimlenmiş olup yapının fonksiyonuna, inşaat için tahsis edilen mali kaynağa, çevre duvarının yapıdaki konumuna ve estetik beklentiye bağlı olarak farklılaşmıştır. Çevre duvarlarının diğer bileşenleri 
gibi kapılar da bu faktörlerden etkilenmiştir. Ancak bu çalışmanın konusunu oluşturan, ana strüktürü basık kemerle oluşturulmuş, genellikle ana giriş yerine yan girişlerde konumlanan kapılar, yapım tekniğine, malzemesine ve bileşenlerine bağlı olarak benzerlik göstermektedir.

\section{Kaynaklar}

\section{A- Kitap, Makale, vd.}

ANONIM, "Piştak", Eczacıbaşı Sanat Ansiklopedisi, C. 3, İstanbul 1997, s. 322.

ARSEVEN, Celal Esad, "Duvar Semeri”, Sanat Ansiklopedisi, C. I, Milli Eğitim Basım Evi, İstanbul 1983, s. 496.

ARSEVEN, Celal Esad, "Kapı”, Sanat Ansiklopedisi, C.2, Milli Eğitim Basım Evi, İstanbul 1975.

ARSEVEN, Celal Esad, “Kemer”, Sanat Ansiklopedisi, C.2, Milli Eğitim Basım Evi, İstanbul 1975.

ARSEVEN, Celal Esad, Istılahat-ı Mi'mariyye (Osmanlı Dönemi Mimarlık Sözlüğü), Kaknüs Yayınları, 2017.

BATUR, Afife, Osmanlı Camilerinde Kemer / Strüktür-Biçim İlişkisi Üzerine Bir Deneme, (İstabul Teknik Üniversitesi Doktora Tezi), İstanbul 1974.

BİNAN, Can, "Kapı", Eczacıbaşı Sanat Ansiklopedisi, Yem Yayınları, C. 2, İstanbul 1997, s. 944-945.

ÇAKMAK, Şakir, Erken Osmanlı Döneminde Taç Kapılar (1300-1500), (Ege Üniversitesi Sosyal Bilimler Enstitüsü, Yayımlanmamış Doktora Tezi), İzmir 1999.

ÇELİK, Serpil, Süleymaniye Külliyesi Malzeme, Teknik ve Süreç, Atatürk Araştırma Merkezi, Ankara, 2009.

ÇORUHLU, Yaşar, "Kapı”, Türkiye Diyanet Vakfi İslam Ansiklopedisi, C. 24, İstanbul 2001, 341-342.

KARADEMIR, Murat, Mimar Sinan Dönemi Yapilarinda Taçkapılar, (Selçuk Üniversitesi Sosyal Bilimler Enstitüsü, Sanat Tarihi Anabilim Dalı, Yayımlanmamış Doktora Tezi), Konya 2014.

KOLAY, İlknur Aktuğ, "Osmanlı Dönemi İnşaat Belgelerine Göre Anıtsal Yapılarda Örtü ve Duvar Sistemleri”, 8. Ulusal Çatı \& Cephe Sempozyumu, Mimar Sinan Güzel Sanatlar Üniversitesi, İstanbul 2016.

KOLAY, İlknur-Çelik, Serpil, “Malzeme ve Teknoloji” Bir Şaheser Süleymaniye Külliyesi, Ed. Selçuk Mülayim, T.C. Kültür ve Turizm Bakanlığı Yayınları, Ankara 2007, s. 125-147.

KUBAN, Doğan, 100 Soruda Türkiye Sanatı Tarihi, İstanbul, 1981.

MÜLAYİM, Selçuk, "Kemer”, Türkiye Diyanet Vakfı İslam Ansiklopedisi, C. 25, İstanbul 2002, s. 252.

NECIPOĞLU, Gülru, The Age of Sinan: Architectural Culture in the Ottoman Empire, Princeton University Press, Princeton-Oxford 2005. 
ÖDEKAN, Ayla, "Bir Mukarnaslı Portal Yarım Kubbesi Geometrik Şemadan Üçüncü Boyuta Geçiş Örneği”, İsmail Hakkı Uzunçarş11ı’ya Armağan, Ankara 1976, 437-445.

ÖDEKAN, Ayla, “Cümle Kapısı”, Türkiye Diyanet Vakfı İslam Ansiklopedisi, C.8, İstanbul 1993, s. 115-116.

ÖDEKAN, Ayla, “Taçkapılar”, Mimar Başı Koca Sinan: Yaşadı̆̆ı Çăg ve Eserleri, Ed. Sadi Bayram, Vakıflar Genel Müdürlüğü Yayınları, C. 1, İstanbul 1988, s. 521-529.

ORBEYI, Nil, "Surrounding Wall of Mimar Sinan's Mosques: Components and Construction", $\begin{array}{llllll}\text { Art-Sanat, } & \text { S. } & 12, & \text { İstanbul } & 2019, & \text { s. }\end{array}$ https://doi.org/10.26650/artsanat.2019.12.0015

SÖNMEZ, Neslihan, Osmanlı Dönemi Yapı ve Malzeme Terimleri Sözlü̆̈̈̈, Yem Yayınları, İstanbul 1998.

SÖZEN, Metin-Tanyeli, Uğur, Sanat Kavram ve Terimleri Sözlüğ̈̈, Remzi Kitabevi, İstanbul 1994.

TANMAN, M. Baha, "Sinan'ın Mimarisi İmaretler", Mimarbaşı Koca Sinan: Yaşadığı Çağ ve Eserleri, Ed. Sadi Bayram, Başbakanlık Vakıflar Genel Müdürlüğü, C. 1, İstanbul 1988, s. 333-353.

HISTORY

TAYLA, Hüsrev, Geleneksel Türk Mimarisinde Yapı Sistem ve Elemanları, Taç Vakfı yayınları, İstanbul 2007.

TUNCER, Orhan Cezmi, “Anadolu Selçuklu Taçkapılarında Mukarnas”, I. Uluslararası Selçuklu Kültür ve Medeniyeti Kongresi Bildiriler, C. 2, Konya 2001, 361-387.

TUNCER, Orhan Cezmi, "Birkaç Selçuklu Taçkapısında Geometrik Araştırmalar”, Vakıflar Dergisi, Ankara 1982, S. 16, 61-76.

TUNCER, Orhan Cezmi, "Kayseri Yedi Selçuklu Taçkapısında Geometrik Düzen”, Vakıflar Dergisi, Ankara 1997, S. 16, s. 105-152.

TURANI, Adnan, Sanat Terimleri Sözlüğ̈̈, Toplum Yayınları, Ankara 1975.

ÜLGEN, Ali Saim, Mimar Sinan Yapıları (Katalog), Ankara 1989, Plate 123.

ULUENGiN, Bülent, Mimari Metaller, Özellikleri, Bozulma Nedenleri, Koruma ve Restorasyon Teknikleri, Birsen Yayınevi, İstanbul 2006.

ULUENGIN, Fatin-Uluengin, Bülent-Uluengin, Bengü, "Osmanlı Anıt Mimarisinde Klasik Yapı Detayları", Yem Yayınları, İstanbul 2001.

ÜNAL, Rahmi Hüseyin, "Osmanlı Öncesi Anadolu Türk Mimarisinde Taç Kapılar”, Ege Üniversitesi Edebiyat Fakültesi Yayınları, İzmir 1982.

\section{B- İnternet Kaynakları}

URL1. https://archives.saltresearch.org/handle/123456789/111287. Kod: AHISTSEHZ003. Erișim Tarihi: 08.12.2019 